\title{
Evolution of Settlement Pattern in Otigba Computer Village, Lagos State and its Challenges to Urban Planning
}

\author{
Chen, S.J., Ogunnubi, T.V., Onakoya, A.O., Yakubu, P.O., Akpan, O.S. \& Nwabufo, C.B. \\ Department of Architecture \\ Covenant University \\ Ota, Ogun State, Nigeria \\ E-mail: sonter.chen@stu.cu.edu.ng
}

\begin{abstract}
Settlement patterns are identifiable distributions of a population in an area which can act as a cultural descriptor highlighting the area's intrinsic and extrinsic characteristics. On the other hand, urban planning is the process of designing land use and the built environment to facilitate human activities and seamless co-existence with nature. Settlement patterns are of interest to geographers, historians, and anthropologists for the insight they offer in how a community has developed over time. This study examined the evolution of settlement patterns, the place of settlement patterns and its challenges to urban planning with specific focus on the Otigba computer village in Lagos State, Nigeria. Qualitative method of research was adopted and data were collected via review of pertinent literature, physical observation of the study area and interview conducted for the traders, occupants of residences in the community and staff of selected Physical planning Authorities in Lagos State. The findings reveal that the study area is comprised of eight streets and was initially designed as a residential layout but has grown exponentially into a commercial cluster of ICT activities which has resulted to urban planning issues of traffic congestion, environmental degradation, over stretched infrastructure, chaos, high level of crime and increased deficit in housing stock. Consequently, this has made it practically impossible for extension of basic amenities and enforcement of regulations which govern the development of land and control of industrial emissions.
\end{abstract}

Keywords: Otigba Computer Village, Settlement Patterns, Challenges, Urban Planning

Aims Research Journal Reference Format:

Chen, S.J., Ogunnubi, T.V., Onakoya, A.O., Yakubu, P.O., Akpan, O.S. \& Nwabufo, C.B. (2019): Evolution of Settlement Pattern in Otigba Computer Village, Lagos State and its Challenges to Urban Planning. Advances in Multidisciplinary Research Journal. Vol. 5. No. 2, Pp 1-10. Article DOI: dx.doi.org/10.22624/AIMS/V5N2P1

\section{INTRODUCTION}

From 1976 to the early 2000s, the population of the world living in cities grew from one-third to one-half. According to UN-Habitat (2004), by the millennium target year, 2050, about six billion of the world's population would be living in cities. This increase is due to urbanization which can be seen as "spontaneous increase in proportion of national or regional population living in cities for the desire to improve one's socioeconomic conditions." (Ekandem, Daudu, Lamidi, Ayegba, \& Adekunle, 2014). One of the major challenges urbanization poses in many urban centers is poor urban planning. This study focuses on Otigba Computer Village Cluster in Ikeja, Lagos State, Nigeria. The Otigba Computer Hardware Village (OCV), most commonly known as Computer Village, is a tech cluster located in Ikeja, the industrial capital of Lagos. The cluster is about 325 square kilometers comprised within eight streets, with Otigba Street being the largest and most populous. This cluster has been involved in ICT hardware and products commercial endeavors for over 12 years, but this area was originally a residential area with a few commercial activities being carried out along Otigba and Pepple streets (Abiola, 2008). 
Over the years, OCV has evolved into a pinnacle of economic prowess which generates about two billion dollars annually (Vanguard, 2013), also providing employment to both low-skilled traders and high-skilled university graduates (Abiola, 2008). According to Oyelaran-Oyeyinka (2006), this cluster has evolved so significantly and rapidly without direct support from the government. The area's unstructured growth has become, even though economically aiding, an urban eyesore. Understanding the urban growth pattern of the area and how the urban planning has failed in creating a properly planned commercial area in OCV, is crucial to avoid a repetition in other areas/clusters.

\subsection{Aim of the Study}

To examine the evolution of Otigba computer village settlement pattern and highlight its challenges to urban planning.

\subsection{Research Questions}

i. How did Otigba Computer Village evolve and develop?

ii. What is the current character and settlement pattern of Otigba Computer Village?

iii. What are the challenges of the settlement pattern to urban planning?

\subsection{Objectives of the Study}

i. $\quad$ To examine the evolution and development of Otigba computer village settlement pattern

ii. To observe the present settlement pattern and character of Otigba computer village

iii. To highlight the challenges of the settlement pattern to proper urban planning

\section{LITERATURE REVIEW}

\subsection{Evolution of Settlement Patterns}

Settlement patterns generally mean the shape or form of settlements. It is the way in which different elements of the settlement from buildings, roads, rails and other infrastructure are arranged. It is also the idea behind which these elements are distributed within the urban environment; these patterns are relevant to geographers, historians, anthropologist, and architects to give insight of how an area would develop over time (Linard, Gilbert, Snow, Noor, Tatem, 2012).

Historically, people built their dwellings together for companionship, safety and to share services, but over time due to population increase the growth creates a distinct settlement or land use pattern. This is not to say that population is the only factor that affects evolution settlement patterns. Oyelele (2001), noted that spatial variation in climate, natural resources and physiography are major factors that influence the evolution of settlement patterns. Civilisations in history flourished and grew around river banks and coastal areas directly leading to period of industrialisation, human population growth and a reduction of rural and urban lifestyles. Factors such as industrialisation brought buildings together forming connected cities which linked by different transportation modes; this in itself is a pattern.

Generally, the Encyclopaedia describes all settlements to contain three major parts namely; Central business district (CBD); this is the centre of the settlement that contains most of the public facilities ranging from hospitals, commercial facilities to schools. The inner city and the suburbs are the other two parts.

Evolution of settlement patterns can be characterised into three methods namely;

i. Linear method: this is where buildings are arranged in lines following a road network or other forms of transport route

ii. Dispersed method: this is where buildings as well as other elements of the settlement are scattered around.

iii. Nucleated method: this is where elements of the settlement are situated around a central core. 
In a fully grown settlement, there can be a combination of the above methods. This creates an integrated environment for the city to work (Oyelele, 2001). Lagos has grown from a small slave port in the 1800 to the most important Port in the West African coastline. The development of the urban profile in Lagos has its focal point from colonisers who lived majorly on Lagos Island. In 1914, Lagos State became the capital of the protectorate of Nigeria up till 1991 when the capital was moved to Abuja the settlement pattern of Lagos is directly affected by human population. These factors created an economic boom and in turn Lagos experienced rapid growth leading to the opening of other areas.

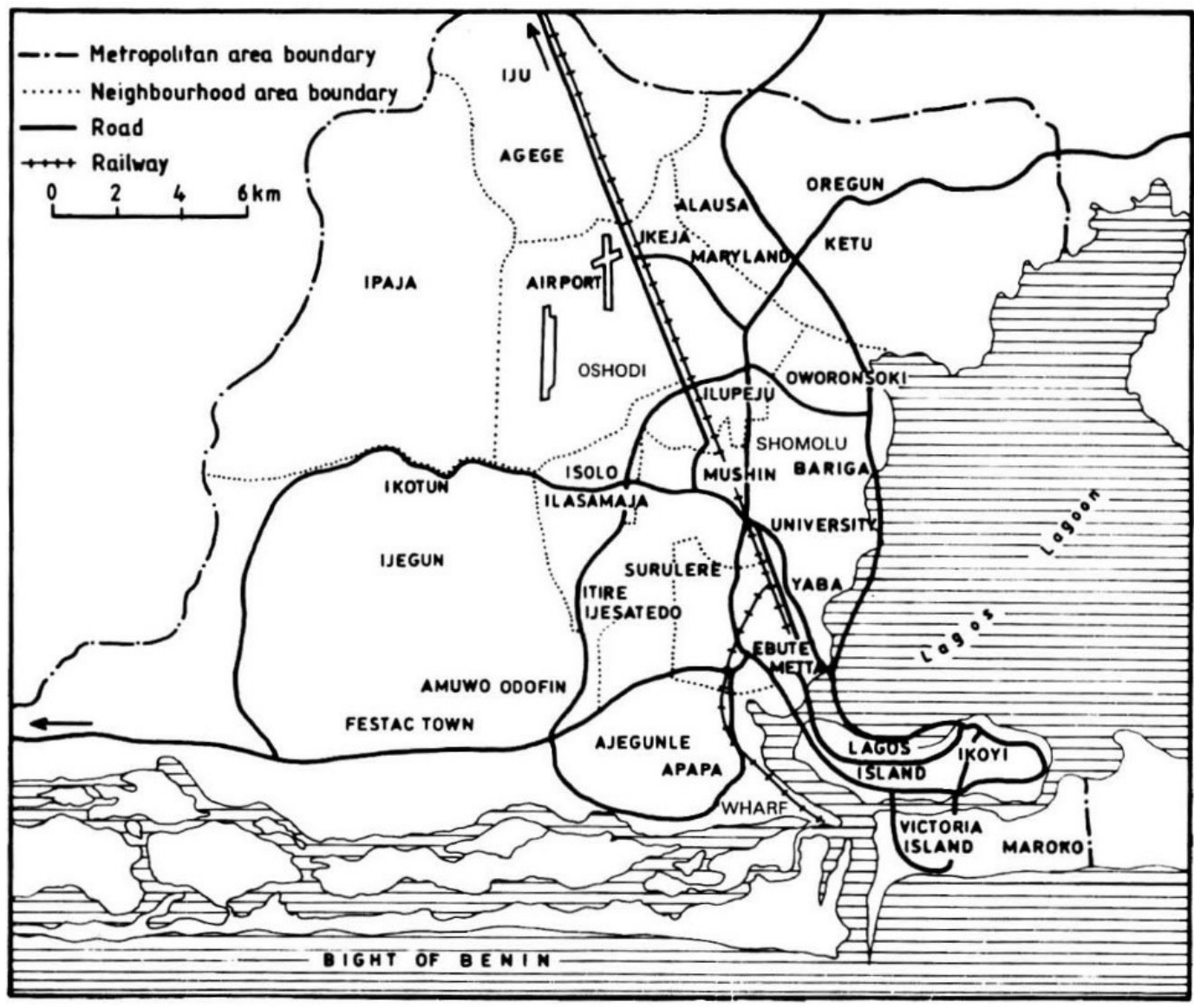

Figure 1: Map of Lagos State (Google, 2018)

\subsection{Advent and Evolution of Otigba Computer Village Cluster}

From inception of Lagos in 1967, the state was divided into Ikorodu, Badagry, Lagos, Ikeja and Epe also popularly known as IBILE which alludes local in Yoruba language. Ikeja as one of the regions was made the capital of Lagos in 1976 because of the Government's progressive plan for the region (Omolayo, 2017). The siting of the secretariat building in Ikeja and construction of roads by the government attracted artisans and heralded the commercialization of the area. The construction of Murtala Mohammed Airport in 1979 was accompanied by a warehousing trend in the region. Freight forwarders and airlines started occupying the region to foster their activities because of its proximity to the newly commissioned Murtala Mohammed Airport. 
In the 1960s before Nigeria gained independence, the Otigba street and its environs were wide expanses of farmlands and no market existed for phones, laptop repairs, general hustling and sundry items in that area. The geographical location of the present ICT cluster was sparsely a residential settlement (Abiola, 2006). However, in the 1970s, the government tarred the Otigba Street and artisans were attracted to that area. There were offices for corporate bodies, shops for barbers, tailors and other small business but there was no computer village then. In the 1990s, the Otigba community became the commercial nerve center of Ikeja as the cluster originated from the sales and repairs of stationaries, printers, office equipment, photocopiers and branded computers (Abiola, 2006).

The growth of this beehive of computer cluster was a result of the high demand for peripherals and computers from educational institutions and businesses in Lagos state. The quiet neighborhood of Otigba Street which was designed for residential purpose became a major business district thus assuming an agglomerative character of a commercial cluster thereby converting residential buildings into commercial complexes. The introduction of the Global system for mobile (GSM) in 2001 increased the intensity of ICT activities in the area as the market further evolved into a place for phone repairs, software downloads, unlocking, memory cards and batteries. By the year 2003, the ICT cluster had over 3000 outlets for sales and repairs of computer, phone and its accessories. The locale of the settlement significantly changed into full operations by retailers, importers and notably builders of computer clones. The exponential growth has led to the direct importation of computer parts and accessories and generates estimated yearly revenue of $\$ 2$ billion.

\subsection{Urban Planning Challenges Associated with Otigba Computer Village Cluster}

Urbanization is one of the most significant megatrends shaping the world in the 21st century (Allison, 2004). Over the last two decades, Lagos State has experienced a high growth as a result of urbanization with an estimated population of over 21 million people. Lagos State commands a dominate role as the commercial hub of the country and has seriously outstripped the capacity to provide adequate basic amenities for the populace.

Urban planning as the name implies can be premised on a large or very narrow scale, comprehensive in focus, system or people oriented. It is based on concerns for specific geographical spaces in an urban setting (Izueke \& Eme, 2013). Globally, urban centers are diversified in characteristics, economic structure, infrastructure, historical background, patterns of settlement growth and formal planning. But in developing countries like Nigeria, urban Centers like Lagos suffer a great extent from severe environmental and health challenges associated with traffic congestion, lack of access to portable drinking water and proper sewage facilities.

Poor urban planning in the face of rapid urbanization is regarded as one of the enormous challenges confronting many urban centers with particular emphasis to the Otigba Computer Village Cluster in Ikeja which is the basis for this study. The Otigba computer village settlement was designed and approved by the Government to be strictly a residential settlement. However, the exponential growth and conversion of the settlement into a major ICT nerve center has led to environmental degradation as a result of overstretching the available facilities, traffic congestion, confusion and increased deficit in housing stock.

This has hindered the extension of water, electricity, solid waste collections services, sanitation arrangements, road networks and housing. Also, public urban planning authorities such as Lagos state physical planning and development Authority, Ministry of physical planning and urban development, Lagos state physical planning permit authority (LASPPPA) and Ikeja area planning authority (I.A.P.A) cannot properly enforce regulations governing land development and industrial emissions as a result of the settlement pattern. In line with this daunting problems facing urban planning in computer village, the government has proposed to relocate computer village to the ICT Park, Kantangowa in Agbado to curb environmental degradation, housing deficit and traffic congestion in Ikeja. 


\section{METHODOLOGY}

In achieving the objectives of this study, three types of investigations namely; literature review, physical observation and interviews were carried out. Several literatures from books, journals and reliable internet sources relevant to the subject matter were reviewed. The study area was visited, the infrastructure and movement patterns were observed for a period of six hours at five different visits. Traders, residents and staff from Lagos state physical planning and development Authority, Ministry of physical planning and urban development, Lagos state physical planning permit authority (LASPPPA) and Ikeja area planning authority (I.A.P.A) were interviewed separately.

The interviews for the Planning Authorities were structured based on eight open ended questions. While the traders and residences were asked about their challenges in terms of difficulties in carrying out their daily businesses. The questions are as follows;

1. What is the settlement pattern of computer village?

2. What plans does planning authorities have for computer village settlement?

3. What are the challenges of enforcing planning regulations in computer village?

4. What are the challenges with proposed new buildings in computer village settlement?

5. What are the challenges with road networks (new and old) in the settlement?

6. How has building regulations adjusted the present settlement pattern

7. What are the challenges of waste management in the settlement?

8. What are the number of floors, set back rules and area of site?

\section{DATA PRESENTATION AND DISCUSSION}

\subsection{Findings from the Physical Observation of the Study Area}

The area is bounded by Simbiat Abiola Way on the west, Obafemi Awolowo way to the North and Kodesoh Street to the East. Figure 1 shows the map of the study area.

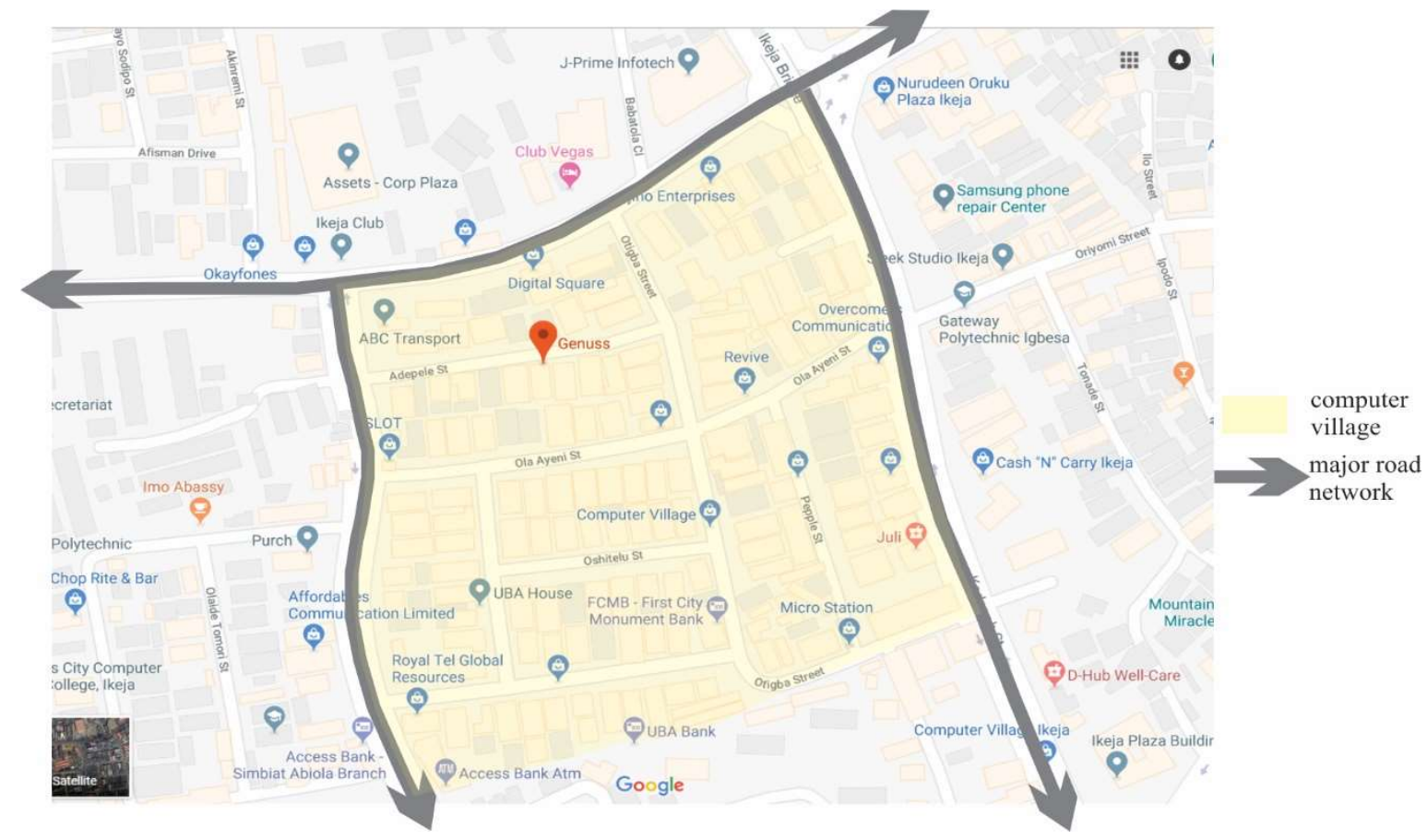

Figure 2: Map of the study area (Google maps, 2018) 
The total area is approximately $183,485.80 \mathrm{~m}^{2}$. It has a linear settlement pattern of clustered buildings with about $1 \mathrm{~m}$ as the minimum set back and the urban profile is midrise with buildings of generic height between two floors and four floors. From the survey, traffic congestion was constantly observed on Obafemi Awolowo way as a result of the activities from the commercial cluster. The access into the commercial cluster is shown in Plate 1.

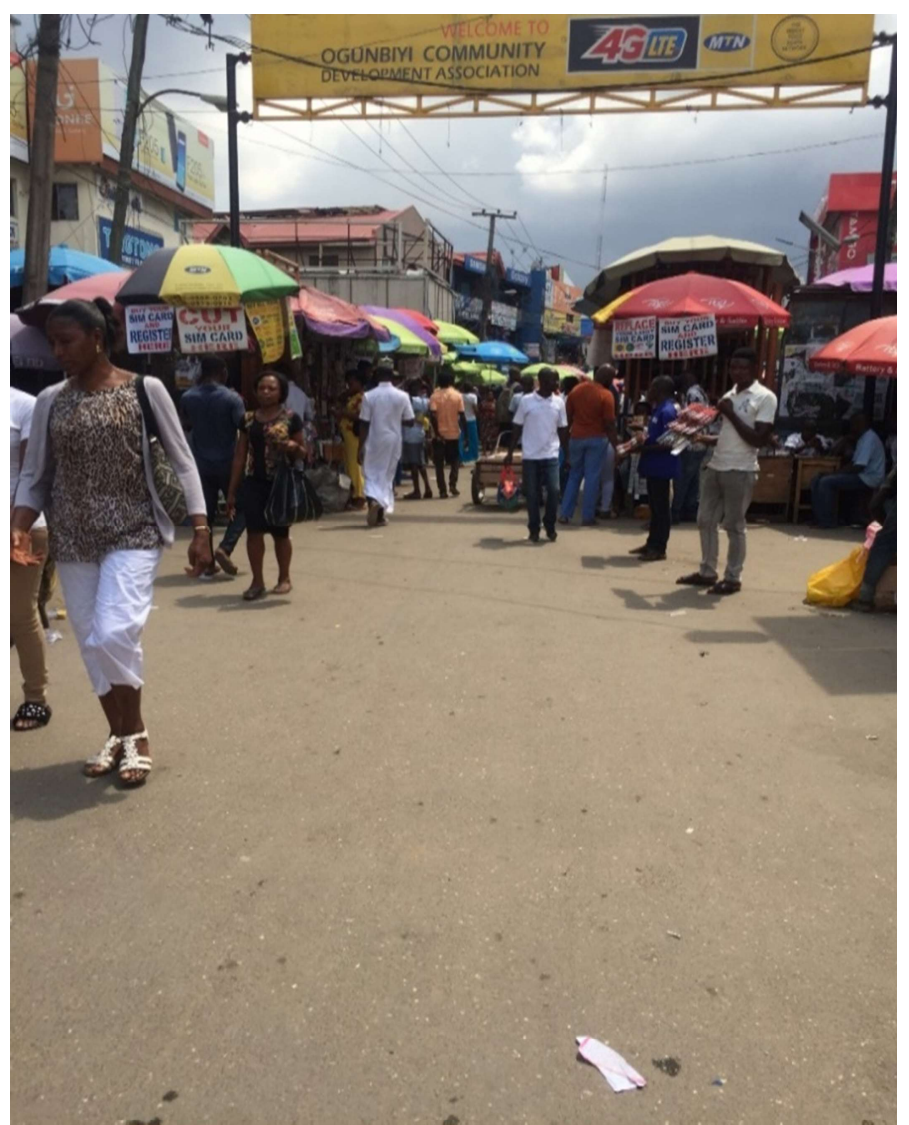

Plate 1: Entrance to Otigba Computer Village

Plate 1 shows one of the entrance gates leading into Otigba street computer. The street is characterized by a $6 \mathrm{~m}$ road with drainages on both sides, seller shacks by the road side and continuous human traffic. The continuous movement of people and the encroachment of traders on both sides of the road make it extremely difficult for vehicles to move. The movement is usually one vehicle at a time. This trend makes urban planning in the area difficult, leaving the planning authorities with redevelopment/clearance as the only viable urban renewal strategy. 


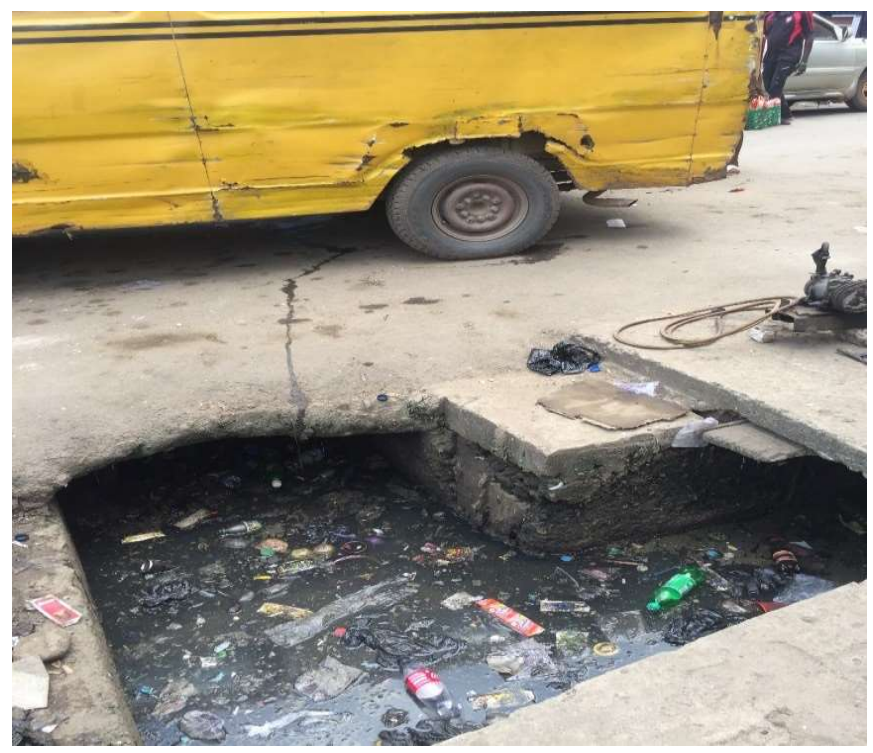

Plate 2: Poor condition of the drainage

Plate 2 is the representation of the drainage system in Otigba Computer Village. Every drainage network in the area is clogged by plastic wraps, plastic bottles, debris and other solid waste materials. This increases the propensity of the area to flooding during heavy rainfall.

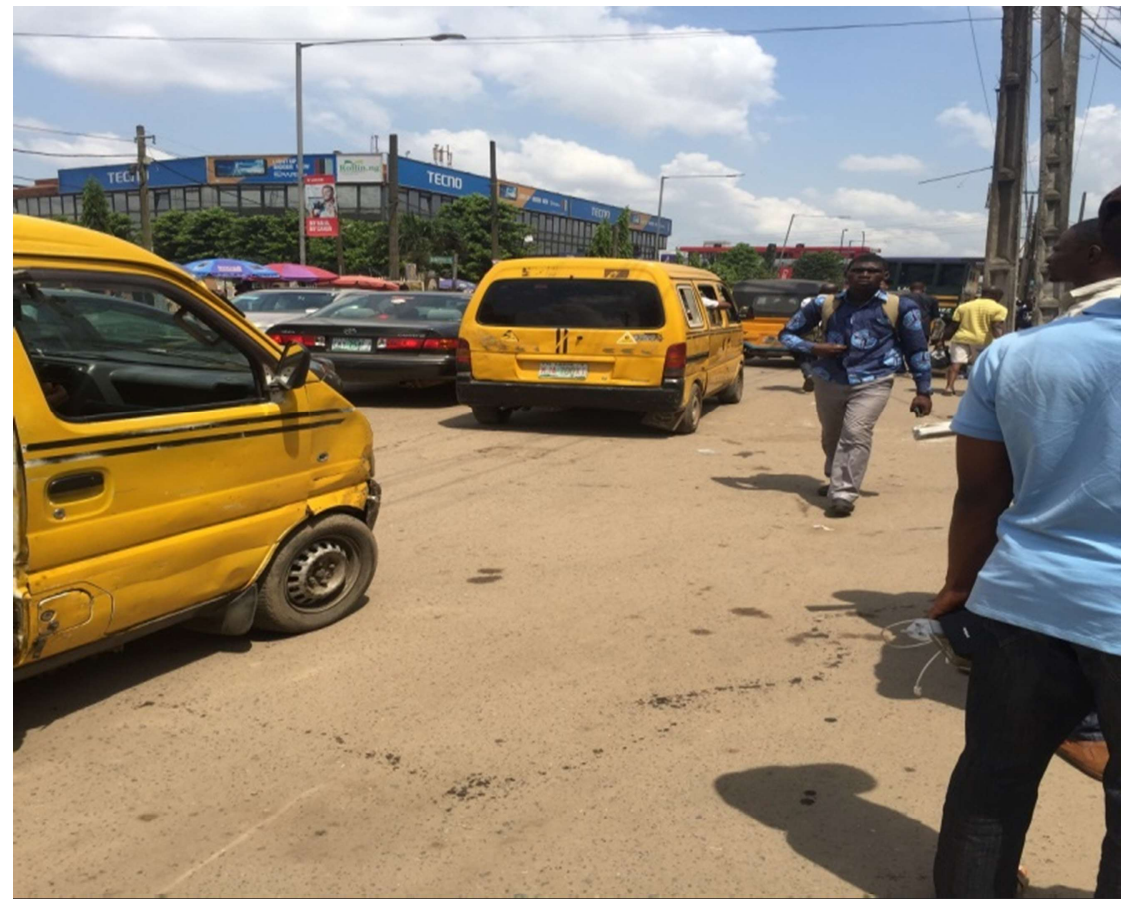

Plate 3: Traffic congestion on Awolowo road 
The commercial viability of Otigba Computer village generates much human traffic. The amount of users/costumers of the area has shown negative influence on the state of movement of the vehicles along the major road (Awolowo road). There is also no designated parking lot or complex to service this community.

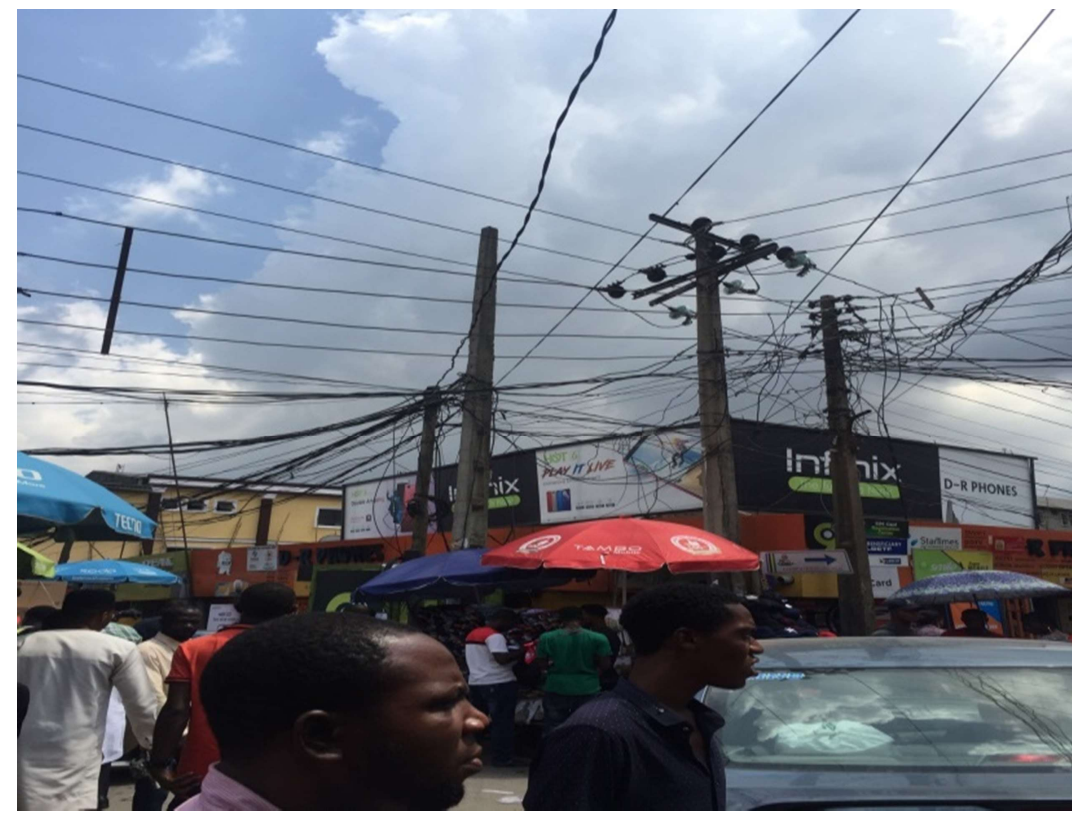

Plate 4: Haphazard electric cable connection

The major source of energy is from electric poles with overhead cables which are haphazardly connected. The cables pose great danger to the users of the community as some drop as low as 2.7 meters.

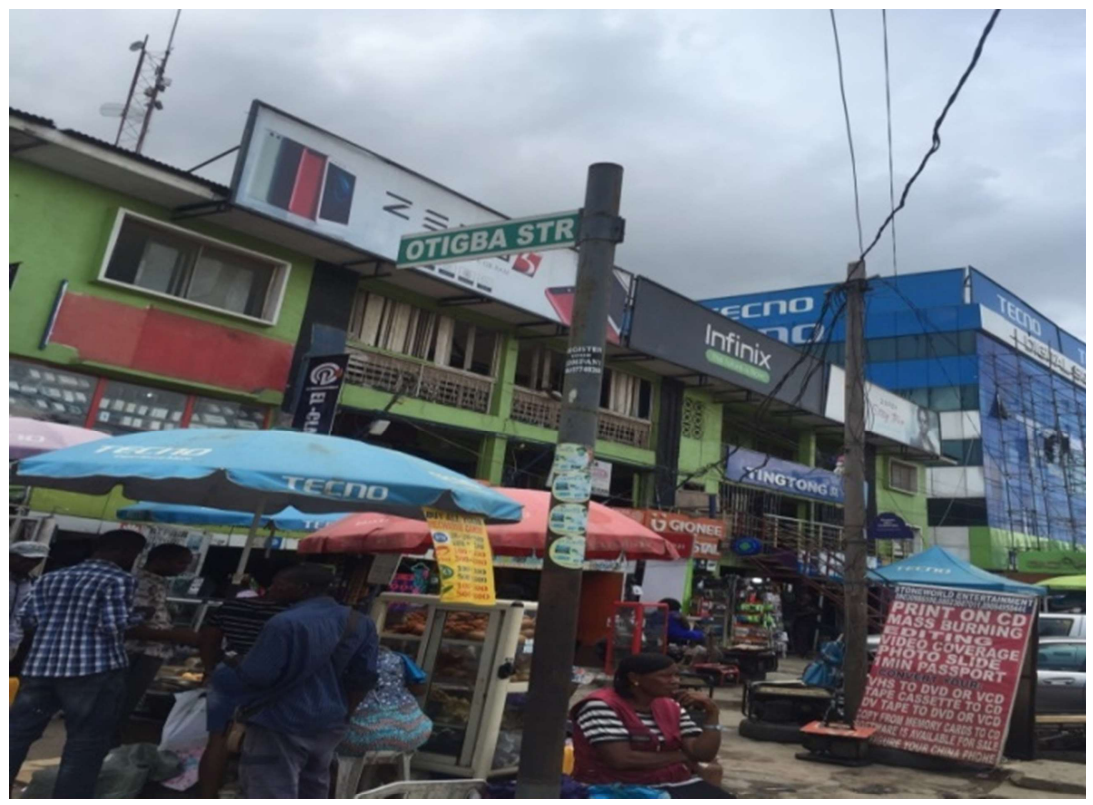

Plate 5: Building typologies and setbacks 
Otigba street is characterized by commercial building typologies of two storey and above with building setbacks between $1 \mathrm{~m}$ and $3 \mathrm{~m}$. Due to the building height, customers would rather buy from the shop fronts on the ground floor. This creates an avenue for increased encroachment of seller shacks unto the road.

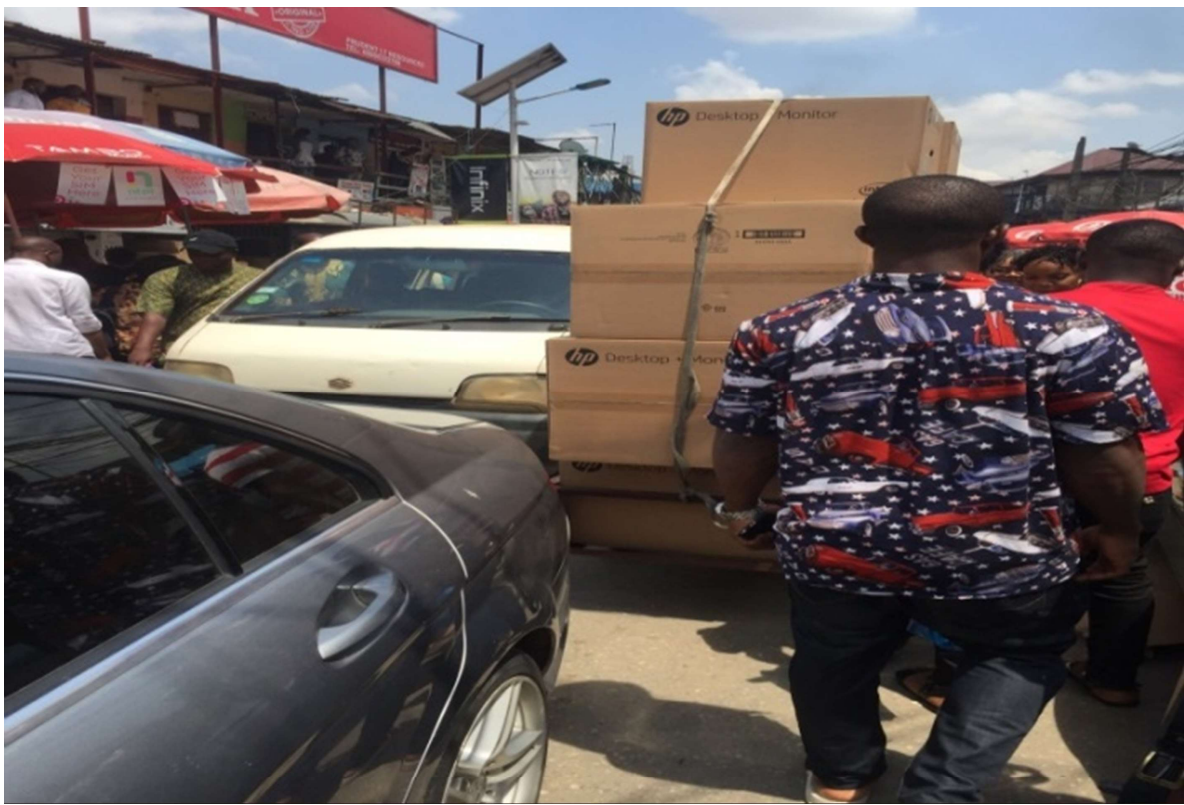

Plate 6: Encroachment of traders unto the road

There is an encroachment of seller shacks unto the road which moves buyers further unto the road. The influx unto the road therefore reduces the motor able part of the road from $6 \mathrm{~m}$ to about $3 \mathrm{~m}-4.5 \mathrm{~m}$ which prevents the easy flow of traffic.

\subsection{Findings from Interview}

Respondents on site confirmed the transition of the area from a residential area to a commercial area. Most of them once lived there and the commercialization of the area led to increase in rent. This (rent) is one of the major factors of the settlement transition in urban function. The interview result is consistent with findings of Abiola (2006), that Otigba Computer village evolved from what was a sparse residential area. Even in the area's surface disorganization, it is still guided by rules. The gates are opened and closed at particular times, all other gates except the main ones are closed by $9 \mathrm{pm}$ and the main one by $10 \mathrm{pm}$. The residents are faced with challenges of noise from the traffic congestion, poor indoor environmental quality due to emissions from various generators, high crime rate and gross inadequacy of basic amenities such as pipe borne water, road networks, access to natural lighting and ventilation which makes sustainable living impossible. However, the respondents noted that the relocation scheme proposed by the Government will negatively affect their businesses due to the distant location.

Staff of the selected physical planning Authorities synonymously identified the settlement pattern in Otigba as a linear settlement with buildings along the eight streets bounded by Simbiat Abiola way on the west, Obafemi Awolowo way to the North and Kodesoh Street to the East. They noted that the Lagos State Government under the distinguished leadership of Governor Ambode has proposed a relocation scheme for the commercial cluster located at Katangua, Agbado area of Lagos State with four thousand shops, shopping plazas, banking halls, parking halls, hotels and a helipad. This relocation plan has become imperative because of the negative effects of not aligning with the original master plan of Lagos Metropolis which the computer village should have been a residential area. 
The planning authorities also noted that the change in land use has given the area a different identity thus making enforcement of setbacks and other building regulations practically impossible. Also, waste management in the study area has become a serious challenge thus leading to clogging of drainage networks and exposing the area to unsafe conditions.

\section{CONCLUSION}

Otigba computer village was originally planned as a residential area but grew into the present commercial area; this was influenced by many factors such as the construction of Awolowo road, Otigba Street and the high demand of computers and peripherals from surrounding institutions. Its settlement pattern is currently characterized by mid-rise buildings with inadequate set-backs, over-populated pedestrians and poor service facilities. All these lead to an untidy urban environment which causes congestion, crime, and a general urban profile that is not healthy for sustainable living. Study shows that the Lagos government in 2018 has planned to clear out the commercial activities in the area to a new site and redevelop it into a residential area as originally planned. This study points out that based on the settlement pattern growth factors, this Lagos government proposal may not be successful.

The study recommends the development of Otigba computer village into a mixed-used area with residential and commercial facilities, provision of necessary services that would make the urban environment work, create and enforce rules that keep the urban profile in shape for healthy and sustainable living. It is also recommended that further studies be carried out to know the plight of the traders and residents before undertaking and urban renewal scheme for Otigba computer village, Lagos State.

\section{REFERENCES}

1. Abiola, B., O. (2006). "Knowledge, Technology and Growth: The Case Study of Otigba Computer Village Cluster in Nigeria." Unpublished paper, Knowledge for Development Program, World Bank, Washington, DC.

2. Abiola, B. O. (2008). The Otigba Computer Village Cluster in Nigeria. In D. Z. Zeng (Ed.), Knowledge, Technology, and Cluster-based Growth in Africa (pp. 65-76). Washington, D.C.: The World Bank.

3. Allison M., G. (2004). Urban Opportunities: Perspectives on Climate Change, Resilience, Inclusion and the Informal Economy. Wilson Center, Washington, DC.

4. Ekandem, E. S., Daudu, P. I., Lamidi, R. B., Ayegba, M. O., \& Adekunle, A. (2014). Spontaneous Settlements: Roles and Challenges to Urban Planning . Journal of Sustainable Development Studies, 6(2), 361-390.

5. Izueke, E., M., \& Eme O.,I. (2013). Urban Planning problems in Nigeria: A case study of Onitsha Metropolis of Anambra. Singaporean journal of business economics and management studies.

6. Linard, C., Gilbert M., Snow R.W, Noor A.M \& Tatem A.J (2012). Population Distribution, Settlement Patterns and Accessibility Across Africa. PloS ONE 7(2): e31743.

7. Omolayo, O. (2017). (Ikeja Computer Village: what it was, what it will always be. Retrieved September $22^{\text {nd }} 2018$ from https://techpoint.africa/2017/05/12/ikeja-computer-village-feature/

8. Oyelaran-Oyeyinka, B. (2006). Learning in Local Systems and Global Links: The Otigba Computer Hardware Cluster in Nigeria. Maastricht: UNU-MERIT Working Papers.

9. Oyeleye, D. A. (2001). Settlement geography. University of Lagos Press.

10. United Nation Centre for Human Settlements (UN-Habitat). (2004). Cities -Engines for rural Development. Habitat Debate, 10(3), pp. 1-23.

11. Vanguard, Nigeria. (2013, April 18). Computer Village generates $\$ 2 b n$ annually to economy minister. Retrieved October 25, 2018, from Vanguard: https://www.vanguardngr.com/2013/04/computer-village-generates-2bn-annually-to-economyminister/ 
Advances In Multidisciplinary

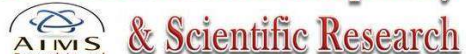

A Multidisciplinary \& InterdisciplinaryJournal

Vol. 5 No. 2, June, 2019 